\title{
Innovative Teaching: A Need to Encounter the Modern Classroom Challenges
}

\author{
Anup Denzil Veigas ${ }^{\mathrm{a}}$ V.M. Berlin Grace ${ }^{\mathrm{b}}$ and D. David Wilson ${ }^{*}$ \\ A*Deparment of English, Karunya Institute of Technology and Sciences, Coimbatore-641 114, Tamil Nadu, S.India \\ bDepartment of English, Karunya Institute of Technology and Sciences, Coimbatore-641 114, Tamil Nadu, S. India \\ 'Department of Biotechnology, Karunya Institute of Technology and Sciences, Coimbatore-641 114, Tamil Nadu, S. India
}

Article History: Received: 11 January 2021; Accepted: 27 February 2021; Published online: 5 April 2021

\begin{abstract}
Teaching a language and addressing the need of the learners is a complex and challenging exercise. Language plays a prominent role in teaching learning process; however, when it comes to teaching of English language, these challenges multiply especially, within the classroom context because of the learners and their diversity of choices. The Irony behind teaching and learning of English language lies in its context in the global level. English Language seems to have many challenges because of the need to proficiency, competency and fluency of users who are capable of utilising the language skills mainly, LSRW (Listening, Speaking, Reading and Writing) to gain employment in global markets. But today, teaching the learners the skills of the language has become more challenging because the learners exhibit a negative feeling to language classes. The present paper emphasises on making teachers more adaptable for the teaching process by avoiding various classroom discrepancies and preparing the learners to utilize new methods for better and effective skill-based language learning.
\end{abstract}

Keywords: Classroom, language, proficiency, learning Methods, challenges

\section{INTRODUCTION}

In today's world, classroom teaching has taken a massive turn from the traditional teaching days. If we look at the language classrooms, we see a mixture of students based on their background, mother tongue influence, their interests towards the English language etc. Today, we are facing more complex and competitive world around us, as our resources are being tested with more intensity. So, the language teaching sector is directly influenced and teachers as well as students are expected to rethink, modify and execute certain skill-oriented activities to make the classroom an interesting learning centre and develop skill-based language learning within the given learning space. One of the methods the teacher can adapt is thetask-based language teaching-learning that is more a learner centric choice that takes the learners through a phase of pre-task, task and post task assessment. This can develop skill-based language learning in the form of skills, giving equal weightage to all the four language skills of Listening, Speaking, Reading and Writing among the learners. Every individual learner can be given care by putting him/her into a task either individually or in a group. At the same time, new tasks can make learning more comfortable and interesting. To define task-based learning in the words of Prabhu: "is an activity that requires learners to arrive at an outcome from given information through some process of thought, and which allows teacher to control and regulate the process" (1).

\section{STATEMENT OF THE PROBLEM}

Today language teaching is considered to be a challenging one. Even though there is no lack in resources, but emphasising on skill-based learning is a dire need of the day. Generally, today's testing pattern is based on recalling and reproducing answers in the exam where testing one's language skill, application and efficiency are completely absent. A student, who completes his studies and ventures into today's competitive world, first faces a challenge of exhibiting his Language skills. But when it comes to this contextual situation, he faces a challenge of qualifying himself to the challenges around him. Many a times they fail at various levels like competitive exams, interviews, group discussion sessions etc. It's a need of today that students must be trained to exhibit their linguistic skills in an appropriate manner and hence an attempt has been made to introduce and invent the task based teaching learning approach into today's classroom setup. This article focuses on various sources and methods of implementing the same into the language curriculum and preparing today's students to be efficient and adaptable to a challenging world.

\section{DEFINING A TASK}

If we try to focus on the word 'task' it can simply be defined in the following terms as,

The word 'task' on the basis of language classroom is a complex idea, because it is a psycholinguistic rationale which is based on language pedagogy. ${ }^{(2)}$

Haberman makes a reference to the traditional linear paradigm of PPP (Presentation, Practice, and Performance) ${ }^{(3)}$. 
Task Based language teaching and learning has to test and measure the proposed qualities of learning as Ayers puts it:

"Standardized texts can't measure initiative, creativity, imagination, conceptual thinking, curiosity, effort, irony, judgement, commitment, nuance, goodwill, ethical reflection or a host of other valuable dispositions and attributes. What they can measure and count are isolated skills, specific facts and functions, the least interesting and least significant aspects of learning" (4).

According to Skehan .P. a task is taken to be an activity in which:

(i)Meaning is primary. (ii) There is some sort of relationship to the real world. (iii) Task completion has some priority and (iv) The assessment of task performance is based on terms of the task outcome ${ }^{(5)}$.

According to Breen, task means "any structural learning endeavour which has a particular objective, appropriate content, a specified working procedure and a range of outcomes for those who undertake the task" (6).

\section{NEED ANALYSIS}

Need analysis is defined as an assessment of Linguistic need of a target group of individuals. The concept of need analysis became an emergence after the 1970's. Summarised as "Needs are those skills which a learner perceives as being relevant to him: wants are a subset of needs, those which a learner puts at a high priority given the time available: and the lack is the difference a learner perceives between his present competence in a particular skill and the competence he wishes to achieve ${ }^{(7)}$

One of the prominent assumptions put forward by Hutchinson and Waters is that the teaching and learning should represent the learner's need ${ }^{(8)}$. Need analysis is nothing but the strategies employed in order to learn the new language. Alright makes a distinction between needs (skills seen by a student as relevant for him or her) wants (the high priority given by the student especially with available time) lacks (difference in present and desired competence). Long states that development of course design is a requirement to have a better view on the part of the students as well as practitioners ${ }^{(9)}$. Needs assessment means to develop Curricula of quality; developers must have valid information on which to base their curricula decisions. The various methods of needs assessment are valuable tools that provide curriculum developers with this information, by incorporating needs assessment in their curricular decisions. Curriculum developers can select options that benefit both the learners and society ${ }^{(10)}$.

Need analysis plays a major part of the study, in order to balance information on the individual and group of individuals as Richterich puts it- Compiling information both on the individual or groups of individuals who are to learn a language and on the use which they are expected to make of it when they have learned it ${ }^{(11)}$. At a more practical level, critical pedagogists design appropriate curricula and classroom activities that facilitate pedagogical instruction between macro level factors such as linguistics, cultural, political, and social dynamics and macro level lived experiences that teachers and students bring with them to the classroom, through problem posing activities they help students problematize familiar and taken for granted issues so that students can perceive and interpret them from a critical perspective ${ }^{(12)}$.

Teaching and learning are two areas that have to be open to frequent changes. When we consider a language classroom most of the focus shifts only to the completion of the prescribed syllabus and the testing is based only on a stipulated area. Though there are many ways prescribed in a syllabus for testing, the testing pattern does not comprise of a comprehensive test that assesses the skills acquired. In order to make students aware about taskbased language teaching and learning, a set group of students have to be taken as samples and task-based teaching and learning practise must experimented on them. The topics to be covered in the present syllabus can be taken up in order to save time and also for testing effectiveness under stipulated restrictions. Students must be introduced to various tasks so that they are able to learn poems, prose, grammar and vocabulary segments through group activities with the help of small tasks that can be assessed using a pre-test and post-test. The success of the study presents the effectiveness of the task-based learning and the results achieved at the end of the task-based teaching learning session and on how the respondents accept novelty in teaching and learning exclusively from the regular methods.

\section{TASK BASED LEARNING AND CRITICAL THINKING}

The final step to reach the critical thinker state is synthesising, what is learnt and the ability to judge accurately. Finally, everything that is learnt has to be applied in different new contexts and only then a learner can be a critical thinker ${ }^{(13)}$. Critical thinking is a cognitive activity associated with using the mind, learning to think critically, analytically and evaluation, ways mean using mental process such as attention, categorisation, selection and judgement ${ }^{(14)}$. The vital theoretical basis for task-based teaching is experimental learning ${ }^{(15)}$.

According to Wigglesworth $\mathrm{G}$ tasks can be used to elicit language production, interaction, negotiation of meaning, processing of input and focus on form, all of which are believed to foster second language acquisition (16). When it comes to learning, learners develop skills when they are pushed to perform in the classroom. They are forced to use whatever language they have to communicate meaningfully and thus, form language structures even if they are grammatically incorrect. In other words they use their own communication strategies by applying their thinking mind and thus, are pushed to the cutting edge of their linguistic competence and language performance ${ }^{(15)}$.

Nuan sees a communicative and non-linguistic goal in task- based teaching. Task is a classroom activity that engages learners for comprehending, interacting and communicating in the target language where conveying 
meaning in the target language is uppermost to learner's mind rather than learning its language form or achieving grammatical knowledge of the language. He also says a task has a sense of completeness to stand alone with a beginning, middle and end ${ }^{(17)}$.

\section{TASK BASED LEARNING AND CLASSROOM IMPLEMENTATION}

Classroom must be reflection of real-life situations, no matter if they are created artificially, however this should enhance competence and confidence which activates acquisition process and increases L2 Learning ${ }^{(18)}$.

Results are always defined as measures or scopes of improvement that helps achieve the success of any research analysis. Seliger makes a reference to language acquisition as: "we have no mechanism for deciding which of the phenomenon described or reported to be carried out by the learner are in fact those that lead to language acquisition" ${ }^{(19)}$. Pine and Boy make their observation of educational responsibility with its results as: Education becomes a meaningless endeavour unless the education acquired has some impact on the human condition ${ }^{(20)}$. Better performance can always be a result of affective achievement ${ }^{(21)}$.

Importance of TBLT and Syllabus design

In today's competent and challenging world, the outcome is derived in terms of the objectives that are outcome from performance, competency or skill. These are quite essential to assess the curriculum and how it has been designed taking today's need, challenges and expectation as the learners progress themselves into the world. The figure I pictures a three-step process formulated into three parts

Input: Means the syllabus design which is framed for the students to learn. How receptive they are and what is expected from them.

Process: It's the different methods used by the instructor or the teacher to teach the students and how acceptable they are in learning and adapting to the method.

Output: Defined as the final outcome or the result. What are the ways and methods that have been used and has it reached the desired output is to be assessed.

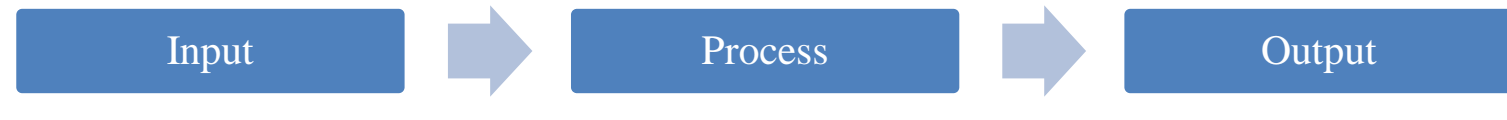

(fig-1)

Figure II: Sample structure for TBL Activity

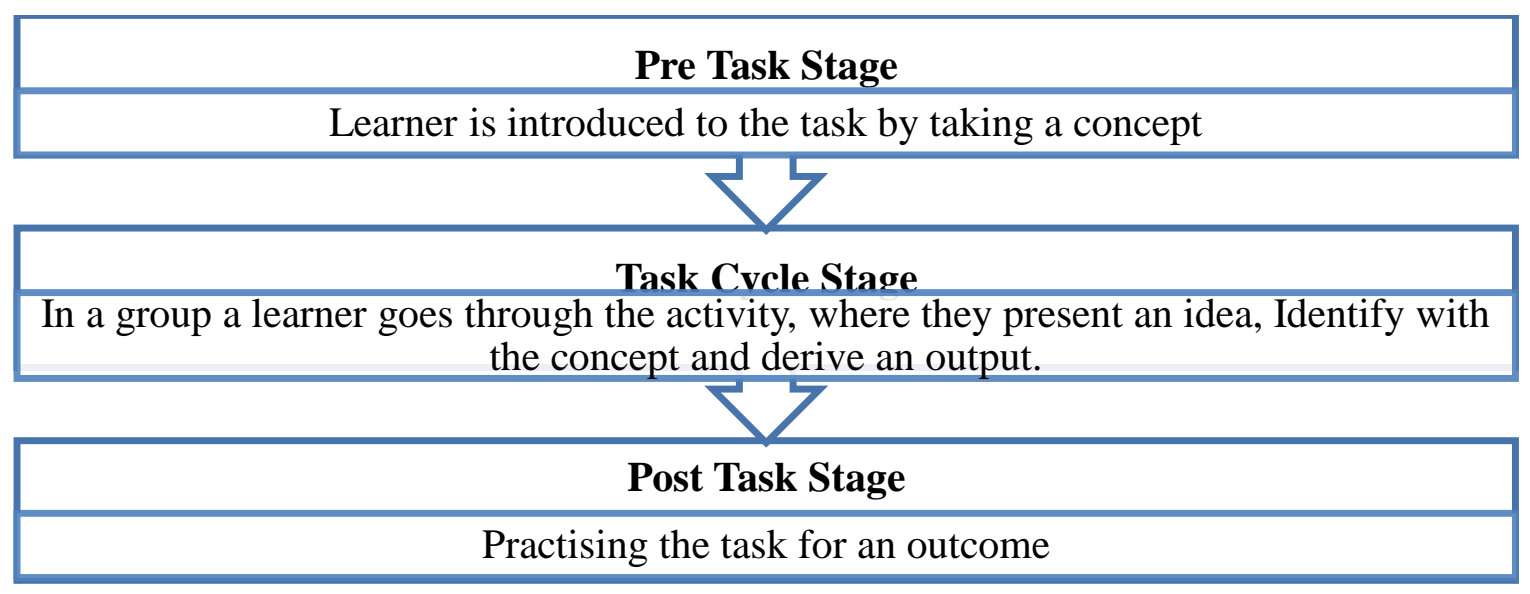

(fig- II).

Classroom Activities for task based learning and its three step evaluation:

\section{a. Learning tenses through quiz}

Pre task: ask students to identify a number of sentences from the text or any reading material and ask them to write it on a notebook. Have a quick Brain storming on the types of tenses and their usage and on the activity task as well. A short video could also be played or a presentation too could be done. Let the students get hands on knowledge with the subject being taught.

Task cycle: split the class into groups of 3-4 with an equal group of smart and weak learners so that the weak learners don't suffer anxiety or fear. A select group of combined learners makes learning and the learners safe and good spirited. Every student will bring out the selected sentences from their text or reading materials and place them as tasks for the opponents.

Post task: each of the group selects a sentence and puts it to the opposite group to solve and identify the appropriate tense forms through quiz. New sentences can be selected and each right answer can be given points and at the end the group with highest points can be declared winners.

Task Outcome: Have the learners understood identification of tenses. Can they figure out the tense form in random sentences? How careful are they in applying it in writing skill and construction of sentences. 


\section{b. Learning words through spell bee}

Pre task: ask students to identify a number of difficult words from the text or any similar words that form antonyms or synonyms for the corresponding word/s. Have a quick Brain storming on the text or the reading material and the activity task as well. A short video could also be played or a presentation too could be done. Let the students become aware as many of them may not know the concept of spell bee.

Task cycle: split the class into groups of 3-4 with an equal group of smart and weak learners so that the weak learners don't suffer anxiety or fear. A select group of combined learners makes learning and the learners safe and good spirited. Every student will bring out the selected word/s from their text or reading materials and place them as tasks for the opponents.

Post task: each of the group selects words or word and puts it to the opposite group to spell and identify the appropriate way of pronouncing and spelling out the words. New words can also be selected and each right answer can be given a point and at the end the group with highest points can be declared winners.

Task Outcome: Have the learners succeeded to learn the words within the text. The success of the learners to identify the differences among the words can be verified. The learner's capability to identify words associated with various genres can be assessed.

\section{TASK BASED LEARNING AND LSRW SKILLS}

Listening skill: considered to be a very useful and important skill also known to be skill of perception, generally this skill is not tested in exam, but can be tested in language labs. Listening tests, the ability to listen and understand. Successful listening and understanding defines the ability to complete the procedure and get a result. Task based activities can be an important outcome generating technique to improve listening in students. If a group has to complete the task given by the opposite group or a result has to be achieved then the entire group must be careful enough to listen and understand what is expected to be accomplished. In future when the learners go to job markets, they will have many challenges in listening to their higher ups or people in authority. Task based learning can develop this essential skill in classroom itself and make learners competent enough in the near future.

Speaking skill: this skill is a test of ability and performance. When a learner has finished with his learning period, he is obliged to take a job, some opt for International exams like IELTS or face interviews and during such circumstances a learner will face the challenge of self introducing himself or answering questions posed by the panel or interviewer. In such situation it's a necessity to convince, and construct an image in the mind of the other. This situation makes a test of once performance, if the person is able to negotiate and convince, he can get a good opportunity of being selected. Task based learning develops an atmosphere in the classroom when groups are given challenges to improve their negotiation skills good listening makes it easy to understand and speak with confidence and develop fluency.

Reading Skill: Generally, this is a very important and much needed skill of today but not given importance by learners. This can be seen in language classrooms when the learners never put efforts to read texts or materials assigned to them. The reading skill is tested in exams generally through reading comprehensions and most of all competitive exams have an exclusive testing pattern for this. Task based learning can be a very significant idea to improve reading skill when many activities can be generated to improvise reading ability. To generate a task on reading it is essential to read the context and content. Though reading may not be a matter for job affair, yet good reading can generate a good vocabulary and crisp language that could essentially be a blessing in disguise.

Writing skill: A much needed and essential skill also can be termed as a survival skill. It is an essential test of vital necessity in almost all exams. Writing plays a major part and role in the entire life span of a human. Writing can have a purpose to convey feelings, emotions or it can be as necessary to put forth objections and clarifications. Writing classifies itself in error free and catchy phrases and articles to represent a writer's calibre and enormous reading experience. Task based learning can be an essential boost to think and discover the potential of a writer's ability through quick writings and content statements. Improved writing can be a essential requirement in job applications or letter writing or other specific purpose writing where competency and presentation becomes a major judgement criteria. It's a need of today that learners convert themselves to be efficient and effective writers.

\section{DISCUSSION AND OBSERVATION}

In this section distribution of students followed by pre-test and post-test performance is analysed.

Table 1: Distribution of students on the basis of Gender and Area

\begin{tabular}{|c|c|c|c|}
\hline \multirow{2}{*}{ Gender } & \multicolumn{3}{|c|}{ Area } \\
\cline { 2 - 4 } & Rural & Urban & Total \\
\hline Male & $22(24.4)$ & $30(33.3)$ & $52(57.8)$ \\
\hline Female & $16(17.8)$ & $22(24.4)$ & $38(42.2)$ \\
\hline Total & $38(42.2)$ & $52(57.8)$ & $90(100)$ \\
\hline
\end{tabular}

The table 1 shows the distribution of students based on the area of division as urban and rural. The total number of students were 90, out of which 42.4 percent were from rural background and remaining 57.8 were from urban area. The proportion of male student was greater than the female. Similarly, in the urban area 33.3 
percent of the males and 24.4 percent of females participated in the study and the number of male students pursuing their graduate studies was more even in the rural area. The total number of students in the rural and urban area was 57.8 percent males and 42.2 percent females. The total students participated in the study were 90 .

Table 2: Performance in the pre-test based on reading,

\begin{tabular}{|c|c|c|c|c|}
\hline \multirow{2}{*}{ Marks } & \multicolumn{2}{|c|}{ Rural } & Male & Female \\
\cline { 2 - 5 } & Male & Female & 01 (1.1) & - \\
\hline $00-05$ & $03(3.3)$ & $02(2.2)$ & $09(10)$ & $02(2.2)$ \\
\hline $05-10$ & $08(8.9)$ & $09(10)$ & $12(13.3)$ & $07(7.7)$ \\
\hline $10-15$ & $06(6.7)$ & $03(3.3)$ & $05(5.6)$ & $09(10)$ \\
\hline $15-20$ & $05(5.6)$ & $02(2.2)$ & $03(3.3)$ & $04(4.4)$ \\
\hline $20-25$ & - & - & $30(33.3)$ & $22(24.4)$ \\
\hline
\end{tabular}

The table 2 represents the performance of students based on reading skills tested through reading comprehension exercises. Considering the rural area majority of them have scored between 05-10 and in urban area majority of them have scored between 10-15. Considering the gender category females have done better than the male students in the pre-test exam. The reading skill performance was based on the reading comprehension.

Table 3: Performance in the pre-test on writing skills

\begin{tabular}{|c|c|c|c|c|}
\hline \multirow{2}{*}{ Marks } & \multicolumn{2}{|c|}{ Rural } & \multicolumn{2}{c|}{ Urban } \\
\cline { 2 - 5 } & Male & Female & Male & Female \\
\hline $00-10$ & $06(6.7)$ & $02(2.2)$ & $02(2.2)$ & $01(1.1)$ \\
\hline $05-10$ & $09(10)$ & $06(6.7)$ & $07(7.8)$ & $03(3.3)$ \\
\hline $10-15$ & $05(5.6)$ & $04(4.4)$ & $10(11.1)$ & $07(7.8)$ \\
\hline $15-20$ & $02(2.2)$ & $03(3.3)$ & $08(8.9)$ & $07(7.8)$ \\
\hline $20-25$ & - & - & $03(3.3)$ & $04(4.4)$ \\
\hline Total & $22(24.4)$ & $16(17.8)$ & $30(33.3)$ & $22(24.4)$ \\
\hline
\end{tabular}

The table 3 shows the pre-test score in writing skills. The writing skill was examined by conducting the exam on grammatical part. Out of 42.2 percent of rural students' majority i.e. 16.7 percent of them have scored 5 to 10 . In the urban areas out of 57.8 percent 18.9 percent of them have scored between 10 to 15 and 16.7 percent of them have scored between 15-20.

Table 4: Performance in the pre-test in Speaking Skills

\begin{tabular}{|c|c|c|c|c|}
\hline \multirow{2}{*}{ Marks } & \multicolumn{2}{|c|}{ Rural } & \multicolumn{2}{c|}{ Urban } \\
\cline { 2 - 5 } & Male & Female & Male & Female \\
\hline $05-10$ & $12(13.3)$ & $08(8.9)$ & $04(4.4)$ & $02(2.2)$ \\
\hline $10-15$ & $09(10)$ & $07(7.8)$ & $12(13.3)$ & $08(8.9)$ \\
\hline $15-20$ & $01(1.1)$ & $01(1.1)$ & $10(11.1)$ & $10(11.1)$ \\
\hline $20-25$ & - & - & $04(4.4)$ & $02(2.2)$ \\
\hline Total & $22(24.4)$ & $16(7.8)$ & $30(33.3)$ & $22(24.4)$ \\
\hline
\end{tabular}

The table 4 represents the performance of students in the speaking skill tested through speaking exercises of self-introduction and presentation. The speaking skill was low among the rural students. The majority of the rural students have studied in Kannada medium which was a barrier for the students to speak in English. In urban area majority i.e., 22.2 percent of them scored between 10-15 and 15-20marks.

Table 5: Performance of students in pre-test in listening Skills

\begin{tabular}{|c|c|c|}
\hline Marks & Rural & Urban \\
\hline
\end{tabular}


Anup Denzil Veigas ${ }^{1}$ V.M. Berlin Grace ${ }^{2}$ and D. David Wilson ${ }^{1 *}$

\begin{tabular}{|c|c|c|c|c|}
\hline & Male & Female & Male & Female \\
\hline $05-10$ & $10(11.1)$ & $07(7.8)$ & $03(3.3)$ & $02(2.2)$ \\
\hline $10-15$ & $08(8.9)$ & $07(7.8)$ & $12(13.3)$ & $09(10)$ \\
\hline $15-20$ & $04(4.4)$ & $02(2.2)$ & $12(13.3)$ & $08(8.9)$ \\
\hline $20-25$ & - & - & $03(3.3)$ & $03(3.3)$ \\
\hline Total & $22(24.4)$ & $16(7.8)$ & $30(33.3)$ & $\mathbf{2 2}(24.4)$ \\
\hline
\end{tabular}

Table 5 represents the performance of students in listening skills tested through reading out a passage and specific questions based on the same. 18.9 percent of rural students have scored between 5-10 and 18.7 percent of the students have scored between 10-15. Considering the urban area 23.3 percent of the respondents have scored between 10-15 and 22.2 percent of the students have scored between 15-20.

Table 6: Performance of students Post Test Reading skill

\begin{tabular}{|c|c|c|c|c|}
\hline \multirow{2}{*}{ Marks } & \multicolumn{2}{|c|}{ Rural } & \multicolumn{2}{c|}{ Urban } \\
\cline { 2 - 5 } & Male & Female & Male & Female \\
\hline $05-10$ & $01(1.1)$ & - & $10(11.1)$ & $06(6.7)$ \\
\hline $10-15$ & $09(10)$ & $05(5.5)$ & $15(16.7)$ & $10(11.1)$ \\
\hline $15-20$ & $09(10)$ & $07(7.8)$ & $05(5.6)$ & $06(6.7)$ \\
\hline $20-25$ & $03(3.3)$ & $04(4.4)$ & $30(33.3)$ & $22(24.4)$ \\
\hline Total & $22(24.4)$ & $16(7.8)$ & & 20 \\
\hline
\end{tabular}

Table 6 represents the performance in the reading skills after introducing the task-based learning method. Both the rural and urban students have performed well. Majority (17.8 percent) of the rural students have scored 15 20 and in the urban area, the performance of student has improved. The percentage of students who have scored between 20-25 has also increased both in rural and urban areas.

Table 7: Performance of students in post-test in Writing skills

\begin{tabular}{|c|c|c|c|c|}
\hline \multirow{2}{*}{ Marks } & \multicolumn{2}{|c|}{ Rural } & \multicolumn{2}{c|}{ Urban } \\
\cline { 2 - 5 } & Male & Female & Male & Female \\
\hline $05-10$ & - & - & $\mathbf{8}(8.9)$ & $04(4.4)$ \\
\hline $10-15$ & $06(6.7)$ & $06(6.7)$ & $12(13.3)$ & $08(8.9)$ \\
\hline $15-20$ & $12(13.3)$ & $08(8.9)$ & $10(11.1)$ & $10(11.1)$ \\
\hline $20-25$ & $04(4.4)$ & $02(2.2)$ & $30(33.3)$ & $22(24.4)$ \\
\hline Total & $22(24.4)$ & $16(7.8)$ & & \\
\hline
\end{tabular}

The table 7 represents the performance of students in the post test. There is a positive improvement in the writing skills and the grammatical errors were reduced drastically. Majority of the rural students have scored between 15-20 and 22.2 percent of the urban students have scored between 15-20 and 20-25. Improving their overall performance.

Table 8: Performance of students in post-test in Speaking Skills

\begin{tabular}{|c|c|c|c|c|}
\hline \multirow{2}{*}{ Marks } & \multicolumn{2}{|c|}{ Rural } & \multicolumn{2}{c|}{ Urban } \\
\cline { 2 - 5 } & Male & Female & - & Female \\
\hline $05-10$ & $05(5.6)$ & $04(4.4)$ & $10(11.1)$ & $06(6.7)$ \\
\hline $10-15$ & $10(11.1)$ & $05(5.6)$ & $12(13.3)$ & $12(13.3)$ \\
\hline $15-20$ & $07(7.8)$ & $07(7.8)$ & $08(8.9)$ & $04(4.4)$ \\
\hline $20-25$ & - & - & & \\
\hline
\end{tabular}




\begin{tabular}{|c|r|r|r|r|}
\hline Total & $\mathbf{2 2}(\mathbf{2 4 . 4 )}$ & $\mathbf{1 6}(\mathbf{1 7 . 8})$ & $\mathbf{3 0}(\mathbf{3 3 . 3})$ & $\mathbf{2 2}(\mathbf{2 4 . 4})$ \\
\hline
\end{tabular}

The table 8 shows the performance in the speaking skills. The rural students have improved in the speaking skill but the confidence level is still low among the rural students 'in comparison with the urban students. Out of 38 students from rural area 14 students have scored between 15-20. Out of 52 students 24 students have scored between 15 to 20 and 12 students have scored between 20-25 marks.

Table 9: Performance of students in post-test on Listening Skills

\begin{tabular}{|c|c|c|c|c|}
\hline \multirow{2}{*}{ Marks } & \multicolumn{2}{|c|}{ Rural } & \multicolumn{2}{|c|}{ Urban } \\
\cline { 2 - 5 } & Male & Female & Male & Female \\
\hline $05-10$ & $04(4.4)$ & $03(3.3)$ & - & - \\
\hline $10-15$ & $07(7.8)$ & $03(3.3)$ & $07(7.8)$ & $06(6.7)$ \\
\hline $15-20$ & $07(7.8)$ & $06(6.7)$ & $12(13.3)$ & $10(11.1)$ \\
\hline $20-25$ & $04(4.4)$ & $03(3.3)$ & $11(12.2)$ & $06(6.7)$ \\
\hline Total & $22(24.4)$ & $16(17.8)$ & $30(33.3)$ & $22(24.4)$ \\
\hline
\end{tabular}

The table 9 represents the performance of students in the listening skills. The listening skills showed improved performance after the task-based learning was introduced to the students. 14.5 percent of rural students have scored between 15-20 and 18.9 percent of the students have scored between 20-25 marks which is an overall improvement.

\section{IMPLICATION AND OUTCOME OF TASK BASED TEACHING- LEARNING.}

Task based language teaching is an important source outcome in the process of second language acquisition. According to Solares, its role is measured in the current language pedagogy. The concept of task teaching is an active exercise of today because it makes the learners creative in working of tasks and motivates them because they become the creators and participants in activities. They are motivated and they are expected to display their creativity and exhibit skills of thinking and persuasion. The teacher can cater to the needs of the students by emphasising on floor testing of concepts rather than wait for the academic exams. The learners can gain academic knowledge that happens through academic discourse. The whole process of task generation and learning can be a unified whole as the tutor and the students work together in situations by developing discussions and open evaluation. The student work in groups as they understand the strength and weakness of each other within the same group and in a classroom context. The process gives them ideas to reflect, develop and practise skill association and implementation in acute circumstances as they converse, understand, apply and create various activities on self or group mode.

The method to assess student's performance was done through exam in all the four language skills, the testing pattern was based on the IELTS exam pattern. The writing skill was tested by essay writing, story completion. The Reading skill was based on Reading Comprehension exercises, the listening skill was tested through making students listen to a passage and answer the questions based on the same and the speaking skill was tested based on self-introduction and presentation on specific products. In the writing skill during the pre-test there were a lot of grammatical and syntactic errors which had then improved in the post test performance. Reading skill performance was quite poor in the pre-test but after implementation of task based reading methods the post-test performance witnessed a substantial improvement. Speaking skill was the poorest among both the rural and urban students basically because of poor confidence in the use of language. Listening skill performance was the improved one, among all the other skills in the post test as it saw a rapid improvement in the overall performance. Through the assessment we can observe that task-based teaching and learning is able to improve the overall performance of the students.

\section{CONCLUSION}

The major problems and drawback on task-based teaching method is that the students are not aware about the teaching approach of tasks and most of them have never gone through such learning. Lack in availability of resources, textbooks and materials, time limit, large number of students these are other problems and challenges. The redesign and rework of the materials could always make task based learning a solution to problems of language learning but the challenge is accuracy. The teachers have also a role to play by updating themselves into this method and another major hurdle is to devise an appropriate task for that particular context. Task based learning could be taken up by subjective teachers in order to design tasks and syllabus that will be effective in solving the learners needs. Finally, to sum up task-based teaching may not be able to transform a learner into a sophisticated person within a time frame given but it's the need of the present time with learners living at a technologically advanced world and seeking activity mode of learning, compelling them to traditional method makes them vulnerable and inactive. Task teaching if used methodically can become a major factor in developing the LSRW skills among the learners today. 


\section{REFERENCES}

1. Allwright . R, What do we want teaching materials for? ELT Journal 1981;36 1:5-18.

2. Ayers, W. To Teach: The Journey of a teacher. New York: Teachers College Press; 1993

3. Breen M. (1987). Learner contribution to task design. In C. Candlin and D. Murphy (eds.) Language Learning Tasks (pp.26-27) Englewood Cliffs, NJ: Prentice Hall.

4. Cottrell S. Critical Thinking Skills: Developing Effective Analysis and Argument. New York: Palgrave Macmillan; 2005.

5. Dickinson L.Self- instruction in language learning. Cambridge: Cambridge University Press; 1987.

6. Ellis, R. Task-based language learning and teaching. Oxford.Oxford University Press; 2003.

7. Guir A.S. Integrating needs assessment into career and technical curriculum development. Journal of Industrial Teachers Education 2005; 42(1): 59-66.

8. Haberman M. Star Teachers: The ideology and best practise of effective teachers of diverse children and youth in poverty. San Antonio, TX : The Haberman Educational Foundation; 2005

9. Hutchinson .T\& Waters A. English for Specific Purposes: A Learning Centred Approach: Cambridge: Cambridge University Press; 1987

10. Kumaravaidavelu, B. Language Teacher Education for a Global Society. Routledge; 2012.

11. Nuan D. Task - Based Language Teaching in the Asia Context:Defining 'task'.Asian EFL journal,2006;8(3). 12-18.

12. Nuan, D. Task- Based Language Teaching. Cambridge University Press; 2004

13. Pine, G.J. \& Boy A.V. Learner Centred teaching: A Humanistic View; Denver, Colorado: Love Publishing Co; 1997

14. Prabhu, N.S. Second Language Pedagogy. Oxford: Oxford University Press; 1987.

15. Richterich R, editor, Case studies in Identifying Language Needs: Strasbourg :( Council of Europe) :Pearson College Div; 1983.

16. Seliger, H. (1984). Processing universals in second language acquisition In:F.Eckman, L. Bell, \& D. Nelson, editors. Universals of second language acquisition, Rowley, M.A: Newbury House.;1984.p. 161-183.

17. Shehadeh, A.Task- based Language Learning and Teaching: Theories and Applications. In: Teachers exploring tasks in English Language Teaching Palgrave Macmillan. UK; 2005.p.13-30

18. Skehan . P. (1996) Second Language Acquisition Research and Task-Based instruction in J Willis and $D$ Willis (eds Pg:20).

19. Stern, H.H. Fundamental concepts of language teaching. Oxford. : Oxford University Press; 1983.

20. Suvarnalakshmi, G. Developing Critical Thinking through Strategy Training: A Task Based Approach, English and Foreign Languages University;2007.

21. Wigglesworth. Task and Performance-Based Assessment. Encyclopaedia of Language and Education .Springer, Boston ,MA;2008 